\title{
THE POSITION OF MANAGEMENT OF CZECH JOINT-STOCK COMPANIES ON DIVIDEND POLICY
}

\author{
František Sejkora, Pavel Duspiva
}

\section{Introduction}

The concept of distributing economic results belongs unequivocally among the basic financial decisions of management. Dividend payout to shareholders can be considered to be dividing profits while fulfilling legal conditions. For many shareholders, the payment of dividends is an important part of their investment decisions. Dividend policy can be defined as determining the method which provides the basis for whether profits will be withheld, shared or used for other purposes. Financial management must implement dividend policy in accordance with other financial decisions, i.e., primarily with investment (how and in to which activities to invest resources) and financial (what sources to use to finance their activities) decisions. From the perspective of financial theory, dividend policy is usually considered against the backdrop of the company's original goal, which is - according to current financial economics - maximizing the firm's market value. In 1961, economists [27] published a theoretical article with the title: "Dividend Policy, Growth and the Valuation of Shares," which is still one of the most discussed controversies in financial theory. The authors of this article submitted scientific evidence about the fact that a shareholder or potential investor is irrelevant to the company's dividend policy, because this does not influence firm value. In other words, receiving dividends or withholding and reinvesting company profit is considered mutually interchangeable. According to this theory, if the profit is reinvested, the firm's market value increases to the level that the investor would receive in the case of sale of shares plus the equivalent amount of unpaid dividends. Their article was a genuine breakthrough, because, at that point, most economists believed that the appropriate dividend policy would influence the firm's market value. According to the authors, the one determinant which does influence the firm's market value is the firm's investment options, therefore, not the dividend amount. The company should accept only projects with positive net present value when accepting such projects leads to maximizing the firm's market value. This theory is founded on the presumption of the existence of a perfect capital market; according to critics of the theory, this does not exist, because the world is full of market imperfections. Another premise is the existence of absolute certainty when decision-making concerning economic entities and the rational behavior of all participants of the financial market in the case that everyone has access to the same informational content and zero transaction costs. Despite these relatively strong and unrealistic preliminary requirements, it emerges from the authors' work that the dividend does not raise firm value by itself, but only implicitly through the market's imperfections.

A significant reason why companies pay dividends is the existence of the principal-agent theory. To a certain degree, dividend payout can reduce conflicts that can arise on account of the differing interests of individual parties during the administration and management of the company.

Asymmetrical information is one cause of the market mechanism's failure. The actual market does not evaluate known and certain values, but evaluates the prospective trend of a company's current and future yields. When it is assumed that managers have more timely information about the company's actual value and potential, dividend payments carry information about the company's future profitability.

Another significant characteristic that influences individual companies' dividend policy is taxes. More or less, different countries have different tax systems, which categorize capital and dividend yields into frequently differing tax 
groups; for example, there may be high rates of implemented tax dependent on the investor's income.

The firm life-cycle theory of dividends explains how companies adapt payout ratio dependent on their own development when, on one hand, the costs drop for acquiring borrowed capital, and, on the other hand, agency costs are incurred. According to [25], the condition of uncertainty makes dividend decision-making a behavioral question, when an increase in profit is transferred to the dividend only when a firm is certain that it will not have to revise its decision in the future.

The large number of articles appearing (primarily in international literature) is evidence that the problem of dividend policy has not yet been satisfactorily resolved. For the most part, current empirical studies are founded on data that have come out of maturely developed countries. Recently, gaps have been filled in the form of studies founded on data from developing countries. Studies show the existence of significant differences in dividend policy implemented in companies - not only on the market overall, but also within individual sectors. There are only a few papers devoted to dividend policy in professional Czech literature [13], [33], which come from the first half of the last decade.

From theoretical and empirical studies, it is apparent that the significance of dividend policy as a tool for maximizing the shareholders' wealth is not clear-cut for individual companies. If we take into consideration that each company determines its dividend policy as a function of the market imperfection it faces, this conclusion is not surprising.

The goal of this article is to identify factors that have a fundamental influence on dividend payout and to further determine and evaluate the position of management on dividend theories. This goal is current as set within the conditions of Czech joint-stock companies, because deeper studies in this area are not available for recent years. Nevertheless, the greater majority of joint-stock companies currently pay dividends and dividend policy has become a part of their financial policy that is impossible to overlook.

\section{The Reasons Why Companies Pay Dividends}

Various theories have been developed to explain the reasons why companies pay dividends.
According to critics of the thesis about dividend irrelevancy, these authors' [27] model is too abstract and unusable in the real financial world. Looking from the perspective of their potential impact on dividend irrelevance, the authors distinguish three large market imperfections: (1) principal-agency, (2) information asymmetry and (3) taxes [24]. In addition, empirical studies claim that company characteristics such as the phase in a company's life cycle, ownership structure, the number of shareholders and firm size all play a fundamental role in dividend payout. Not least when considering dividend determination, is the behavioral question.

\subsection{Market Imperfections}

The division of management from company ownership leads to agency conflict; this can result in situations where the shareholders' and management's interests do not coincide, and they can even end up working against each other. Management's members centralize the daily managerial agency in their hands, but they are not the investors. This managerial agency requires decision-making, which is regularly supported by the use of quantitative methods [9]. Naturally, this leads to conflict that, on one hand, admits the possibility of the investment's direct devaluation and concern about the ineffective use of entrusted financial resources as well as the possibility of opportunistic behavior on the part of management or minimizing risk when conducting business [18]. To a certain degree, dividend payout can actually reduce this type of managerial conflict. Dividend payout changes the ratio of owned capital and borrowed capital as well as the decrease of financial resources. As a result, the company must take care of necessary financial resources for investment on the financial market. The financial market represents not only an important source for financing enterprises, but also the main supervisory institution overseeing the management's behavior ([10], [17]).

In companies, agency conflict also occurs between the majority and minority shareholders. The authors of [34] state that problems of agency related to significant jointstock interest are more difficult to supervise than problems of agency which occur in relation to delegating management's decision-making powers. The authors of [22] present two models for a company's minority shareholder dividend policy, which are modified and empirically 
tested in various forms. In the first, minority shareholders use their power and request dividend payout because of limited potential for personal reward on the part of the majority shareholders. Empirical studies by these authors [16] support this hypothesis. The second model presumes the dividend is a substitute mechanism for relieving conflict between minority and majority shareholders. Majority shareholders are motivated to pay dividends primarily in countries with low safeguards for minority shareholders with the goal of creating a good company reputation and, therefore, ensuring better access to sources for financing the company. Empirical studies by these authors [19] support this hypothesis.

Finally, the third agency problem concerns the conflict between the firm alone and third parties, primarily concerning company creditors. The authors of [31] present a number of ways for shareholders to expropriate wealth from creditors. One of the most common ways is insufficient investments where shareholders prioritize dividend distribution at the expense of investments in new projects, which leads to increasing risk from the perspective of the creditors. The authors of [5] followed up on this idea in article [22] and consider the dividend to be a substitute mechanism for relieving conflict between shareholders and creditors. In their empirical research involving 35 countries around the world, the authors of [7] come to the conclusion that creditors have a greater influence on dividend politics than shareholders.

The work with information is among the factors that decide about the quality of business activities-therefore it is the resource of inimitable competitive advantages [29]. Another market imperfection is the existence of information asymmetry between shareholders and management. According to the conclusion of the authors of [27] the dividend alone does not increase firm value. Information about expected future profits, which the dividend yields, increases firm value. If the signaling theory is correct, investors can then deduce information about the company's future profitability by changes in dividend policy.

Part of the signaling theory is the assumption of information asymmetry between managers and investors in access to information about company prospects. It is possible to overcome this asymmetry with the help of dividend signaling. In order for this signal to be credible, it must carry costs with it, which limits less successful companies from false signaling using dividends. These costs are generally understood to be higher tax rates [20], though they can be also transaction costs [4] or costs coming from sub-investment [28]. All three models agree on the conclusion that more profitable companies pay higher dividends as well as that higher dividends are linked to higher stock prices.

The extensive empirical research that has been previously conducted does not give clearcut support for the signaling theory. Evidence that a relationship between dividends and stock price exists was confirmed by the majority of empirical research that has been conducted (e.g. [1], [26]). Nonetheless, empirical evidence about whether dividends carry information concerning the firm's future profitability are not so clear-cut. Empirical studies confirming that dividends carry information concerning future profitability are [14] and [32], for example. Conversely, the relationship between dividends and future profit was not confirmed, for example, in this study [2].

For many investors, investment into shares is an important part of their decision-making processes. For situations with at least two alternative solutions, it is possible to successfully apply the methods of multiple-criteria decision analysis [15]. Various tax burdens for dividends and capital yields create different groups of investors interested in various corporate dividend policies. If capital yields are taxed with a lower rate than dividend yields, then investors with higher profits will prefer capital yields. On the other hand, the market has investors with lower or no tax from direct dividends, which are, in relation to the clientele effect, unequivocally for stocks with high dividends. If there is a change in their preferred company's dividend policy, then investors can sell that company's shares, or the company can attract a group of different investors, which can result in this influencing the price of shares.

Empirical verification of this theory is conducted with the help of a drop in the stock price on the ex-dividend date. The authors of [11] were the first to empirically confirm the clientele effect theory. In conclusion, the authors found that investors from the group with higher tax burdens should prefer companies with lower dividend yields and the reverse. In researching the tax effect for the drop of prices on the ex-dividend 
date, empirical studies primarily use changes in tax systems. For example, the authors of [21] corroborated the tax clientele effect, though the tax effect was not upheld in the study by these authors [35], for example.

\subsection{Other Reasons for Dividend Payout}

We can add managerial preference to the list of other reasons why a firm pays dividends. In their research, the author of [25] performed a range of interviews with company managers on their firm's dividend policy. The author alleges that, when there is uncertainty, dividend decisionmaking becomes a behavioral question. One of the most important conclusions was that companies have a set long-term payout ratio. Therefore, joint-stock company management will not implement change in the dividend policy if they are not able to ensure a stable dividend level for the given time interval in the future. Management considers frequent changes in dividend policy to be a negative signal for investors in the form of future economic uncertainty for the company. These conclusions are supported by many empirical studies. The authors of [3] (1997 page of 1032) state: "Lintner's model of dividends remains the best description of the dividend setting process available." The authors of [23] state that over the course of the last 80 years, the number of companies that apply this model of corporate dividend politics has been increasing.

Another key factor is the theory of the firm life cycle. The firm life cycle theory assumes that dividend payout is dependent on the company's developmental phase, where financial indicators such as profitability, size, investment opportunities and capital structure change over time. After reaching a certain life cycle phase, the company is not capable of finding appropriate investment resources for its generated cash flow, and, therefore, distributing financial resources to investors in the form of dividends appears to be the most convenient strategy. This dividend theory explains how companies adjust payout ratio in dependence with their development when, on one hand, costs for obtaining borrowed capital decrease and, on the other hand, agency costs appear [6]. The authors of [12] assert that large, established companies with high profits and slow growth are more willing to pay dividends. The authors of [8] cite the ratio of undivided profit to owned capital as an indicator of life cycle phase.

\section{Research Goal and Methods}

The research concept arose from existent findings for the problematic being investigated. The basic research goal was to establish factors that influence management concerning dividend policy in the investigated sectors and the stance of respondents as to whether dividend policy can influence firm value. The following research questions and hypotheses were established for this purpose:

Research question: What factors influence management when making decisions concerning dividend payout?

Hypothesis H1: Dividend payout influences market imperfections, which results in influencing firm value.

The following sub-hypothesis were defined to verify their validity:

H1a: Dividend policy influences firm value.

$\mathrm{H} 1 \mathrm{~b}$ : Dividend policy influences investment and financial decision-making.

H1c: Dividend policy decreases information asymmetry between management and shareholders.

H1d: Dividend policy decreases agency costs between management and shareholders.

$\mathrm{H} 1 \mathrm{e}$ : Dividend policy reflects the shareholders requirements.

Regarding the fact that the necessary condition for dividend payout is profit, research was aimed at the sector "Production and Distribution of Electricity, Gas and Water," which is most interesting among Czech jointstock companies from the perspective of profitability and frequency of dividend payout. For the reasons of quantitative research, a two-part questionnaire was created. The first part of the questionnaire provided the answer to the research question and contained 20 factors that influence dividend policy in the chosen sector. The choice of factors arose from both theoretical findings on dividend theories as well as empirical examination. Other than this, the respondent had the option to fill in factors not included in the list. This option remained without response. Individual factors were evaluated with the help of a fourpoint scale of importance where $0=$ none, 1 = low, 2 = medium, 3 = high concerning the importance of the given factor. 
For testing the importance of individual factors, the t-test was used; a two-sided hypothesis was tested as to whether the middle value of the factor's importance equals an average of 1.5 .

The second part of the questionnaire verified the group of five sub-hypotheses which were corroborating the main hypothesis of whether dividend policy can influence firm value. The respondents' individual positions were evaluated with the help of a 1 to 5 scale where the value of 5 represented strong agreement, 4 = agreement, 3 = without opinion, 2 = disagreement, and 1 = strong disagreement.

The validity of the sub-hypotheses was determined according to the number of answers obtained. The Wilcoxon signed-rank test was used to verify the significance of individual assertions; in this, a two-sided (or a one-sided) hypothesis was tested for whether the middle value of the median equals 3 (or is larger or smaller than 3).

The starting point for establishing the scope of the basic sample group suitable for research was the Amadeus database. In the Czech Republic, there are 225 companies active in this sector out of an overall number of 25,237 jointstock companies. Of these, the largest number of companies are producers and distributors of electricity, gas, steam and hot water (around $2 / 3$ ); the remainder are concerned with water manufacture and treatment. With regards to the assumption that dividend decision-making is primarily implemented by larger companies and those with a definite history, the basic group was further reduced to exclude companies with a yearly turn-over of under 30 million CZK and companies founded after 2008. The final scope of the basic sample which fulfilled the defined requirements was 159 joint-stock companies active in the investigated field.

The survey took place from November 2013 to January 2014. The questionnaires were distributed to the selected businesses via electronic mail and students from the University of Pardubice. The questionnaire was created for workers in financial management - specifically, members of the executive board, who are assumed to have comprehensive knowledge and an overview of the company. In light of the number of contacted respondents, the authors attempted to ensure a sufficient representative sample. It is possible to estimate the necessary minimal sample size using the following relationship:

$$
n \geq \frac{t_{\alpha * p *(1-p)}^{2}}{d^{2}}
$$

where:

$t_{\alpha}$ is the coefficient of reliability for the selected reliability $\alpha$,

$p$ is the estimate of the relative frequency of surveyed criteria in the basic sample,

$d$ is the required permissible error,

If we require $90 \%$ reliability with a permissible error of $11 \%$, then the minimum number of surveyed respondents is the following:

$$
n \geq \frac{1.645^{2} * 0.16}{0.11^{2}}=35.78
$$

The minimum number of surveyed respondents for determining representation of selection should be 36 .

From the perspective of probable statistics, the sample group was established by nonrandom selection. With respect to the fact that the basic sample is not extensive, all 159 companies were contacted using the questionnaire.

Of the total 159 companies contacted, 44 questionnaires were returned. Two of the returned questionnaires were not entered into the statistical evaluation, because they were not completely filled out. The overall return rate was $26.42 \%$. The representation of companies engaged in production and treatment of water was $45 \%$ of the sample and the rest, i.e., $55 \%$, were producers and distributors of electricity, gas, steam and hot water. On the basis of the above information, we can consider the sample group to be representative.

\section{Research Results}

Table 1 provides the answers to the research question concerning which factors influence management when making decisions about dividend payout. The table illustrates the order of individual factors from most significant to least significant, including descriptive characteristics of the statistics (statistically significant differences are in bold type).

From the data in the table, it is clear that management considers a wide range of factors when devising dividend policy. That indicates that dividend policy among the investigated companies differs, and there is no one factor 
The factors influencing management when making decisions about dividend payout

\begin{tabular}{|c|c|c|c|c|c|c|}
\hline \multirow{3}{*}{ Factor } & \multicolumn{4}{|c|}{ Level of Importance (\%) } & \multirow{3}{*}{ Average } & \multirow{3}{*}{ t-test } \\
\hline & None & Low & Medium & High & & \\
\hline & 0 & 1 & 2 & 3 & & \\
\hline F5 Existing shareholder requirements & $4.76 \%$ & $0.00 \%$ & $35.71 \%$ & $59.52 \%$ & 2.5 & 8.75 \\
\hline F11 Limiting liquidity (access to funds) & $9.52 \%$ & $21.43 \%$ & $45.24 \%$ & $23.80 \%$ & 1.95 & 2.97 \\
\hline F1 The amount of actual profit & $9.52 \%$ & $21.43 \%$ & $45.24 \%$ & $23.81 \%$ & 1.83 & 2.38 \\
\hline F7 Maintaining the target state of debt & $0.00 \%$ & $40.48 \%$ & $47.62 \%$ & $11.9 \%$ & 1.71 & 2.38 \\
\hline F6 The stability of profit & $4.76 \%$ & $35.71 \%$ & $52.38 \%$ & $7.14 \%$ & 1.62 & 2.06 \\
\hline F14 The expected amount of future profit & $7.14 \%$ & $42.86 \%$ & $45.24 \%$ & $4.76 \%$ & 1.48 & -0.22 \\
\hline F12 The actual influence of financial leverage & $9.52 \%$ & $40.47 \%$ & $50.00 \%$ & $0.00 \%$ & 1.4 & -0.93 \\
\hline F8 The expected degree of the productivity of activities & $7.14 \%$ & $47.62 \%$ & $45.24 \%$ & $0.00 \%$ & 1.38 & -1.24 \\
\hline $\begin{array}{l}\text { F13 Investment opportunities (access to profitable } \\
\text { projects) }\end{array}$ & $9.52 \%$ & $52.38 \%$ & $30.95 \%$ & $7.14 \%$ & 1.36 & -1.22 \\
\hline F4 Costs for acquiring new sources of financing & $9.52 \%$ & $54.76 \%$ & $30.95 \%$ & $4.76 \%$ & 1.31 & -1.73 \\
\hline F2 Access to alternative sources of capital & $14.28 \%$ & $45.24 \%$ & $40.47 \%$ & $0.00 \%$ & 1.26 & -2.2 \\
\hline F9 Influence firm value (shares) & $9.52 \%$ & $64.29 \%$ & $26.19 \%$ & $0.00 \%$ & 1.17 & -3.72 \\
\hline $\begin{array}{l}\text { F19 Contractual limitations (e. g., from credit } \\
\text { contracts) }\end{array}$ & $40.48 \%$ & $33.33 \%$ & $14.28 \%$ & $11.90 \%$ & 0.98 & -3.31 \\
\hline $\begin{array}{l}\text { F3 The future state of the economy (macroeconomic } \\
\text { indicators) }\end{array}$ & $19.05 \%$ & $16.67 \%$ & $14.29 \%$ & $0.00 \%$ & 0.95 & -6.09 \\
\hline F17 Maintain the payout ratio & $23.81 \%$ & $66.67 \%$ & $9.52 \%$ & $0.00 \%$ & 0.86 & -7.36 \\
\hline F16 Send out a positive signal to investors (creditors) & $30.95 \%$ & $54.76 \%$ & $11.90 \%$ & $2.38 \%$ & 0.86 & -5.8 \\
\hline F10 Legislative measures & $28.57 \%$ & $64.28 \%$ & $7.14 \%$ & $0.00 \%$ & 0.78 & -8.19 \\
\hline F18 Maintain the history of dividend payout & $35.71 \%$ & $57.14 \%$ & $7.14 \%$ & $0.00 \%$ & 0.71 & -8.54 \\
\hline $\begin{array}{l}\text { F15 Dividend policy in accordance with the } \\
\text { competition }\end{array}$ & $45.24 \%$ & $42.86 \%$ & $11.9 \%$ & $0.00 \%$ & 0.67 & -7.86 \\
\hline $\begin{array}{l}\text { F20 Avoid a warning signal for investors in the form of } \\
\text { lowering the dividend }\end{array}$ & $47.62 \%$ & $52.38 \%$ & $0.00 \%$ & $0.00 \%$ & 0.52 & -12.51 \\
\hline
\end{tabular}

that is unimportant for management. From the perspective of statistical significance, it is possible to divide the given factors in to three groups: i) important, statistically significant factors, ii) average factors for which no statistical importance was demonstrated and iii) factors of below-average importance for which statistical significance was demonstrated.

From the total of 20 factors investigated, respondents specified the following factors as most significant: F5 - Existing shareholder requirements, F11 - Limiting liquidity, F1 - The amount of actual profit and F7 - Maintaining the target state of debt. All these factors are statistically significant at a rate of 0.05 significance.

The most significant factor is F5 - Existing shareholder requirements, which $95.23 \%$ of managers put down as medium to high in importance among the given factors. The course of privatization in the Czech Republic led to the emergence of concentrated ownership, where shareholders more easily force management to act in the shareholder's interests, including 
dividend payout at a corresponding rate. F1 - The amount of actual profit is another important factor. Profit represents the criteria for management's success at assessing entrusted economic sources, and profit is the basic prerequisite for management's decision concerning dividend payout. For this reason are important accounting records because the resulting financial statements and reports help plan and make decisions [30]. According to the respondents, other significant factors assessed that influence decision-making concerning dividends are $F 11$ - Limiting liquidity (access to funds) and F7-Maintaining the target state of debt. In accounting, profit is reported using the accrual concept, which does not indicate the company's ability to generate money with its activities. From the perspective of the corporate financial balance sheet, funds are important, because then the enterprise is capable of fulfilling their commitments, including the ability to pay dividends. The state of debt indicates the reality that a business uses external sources for financing its activities, i. e., debt. The basic problem of a company's financial management is the choice of the correct sources for financing their activities - finding the optimal relationship between owned capital and borrowed capital.

The next group of factors listed by the respondents are those of average importance, but statistically insignificant. The most significant factors in this group are F6 The stability of profit and F14 The expected amount of future profit. This is possible to interpret to mean that managers do not consider dividend decision-making to be a behavioral question in the style of Lintner's model, but make decisions operationally according to the actual situation and primarily according to shareholder requirements. This is confirmed by factors $F 18$ Maintain the history of dividend payout and F17 Maintain payout rate, which are, from the perspective of importance, below-average and statistically significant.

Other factors of average importance but statistically insignificant are F12 The actual influence of financial leverage, F8 The expected degree of the productivity of activities, F13 Investment opportunities (access to profitable projects) and F14 Costs for acquiring new sources of financing. It is possible to include these factors under financial decision-making concerning investments, when the optimal chosen combination of factors is able to raise company profit, which is able to be subsequently distributed to shareholders in the form of dividends.

The remaining ten factors are of belowaverage importance and statistically significant. This group includes the factor F2 Access to alternative sources of capital. Its low level of importance indicates that obtaining sources for financing is clearly not difficult for managers. Low debt and company profitability provide potential creditors with a suitable, low risk investment opportunity. Factor F19 Contractual limitations is given a belowaverage rating, but the importance of this factor within the conditions of the investigated field was confirmed as a part of the survey. Two respondents stated that their current credit contracts contain clauses forbidding dividend payout.

Tables 2-6 below verify the validity of hypothesis H1. Five sub-hypothesis were defined for its verification. The first sub-hypothesis determined whether dividend policy influences firm value. The question of whether or how dividend policy influences firm value has been following academic workers and managers for decades. The authors of [27] proved that, under a perfect market, firm value does not depend on dividend policy. The wording of the questions and relative frequency of answers expressing the position of respondents on dividend policy and firm value are listed in Table 2 below.

The most explicit agreement was given by the respondents to the statement that dividend policy should attempt to maximize firm value for shareholders and dividend policy is the main factor that influences a firm's market value with $83.3 \%$ and $66.67 \%$ of respondents respectively expressing slight or strong agreement. Only $54.76 \%$ of respondents agreed somewhat or strongly with the statement that a change in the dividend influences firm value. All of the statements are statistically significant.

A summary overview of the number of answers for the three statements concerning dividend policy and firm value provides support for sub-hypothesis $\mathrm{H} 1 \mathrm{a}$ - that dividend policy does influence firm value. This conclusion is therefore in conflict with the theory of dividend neutrality from source [27].

The second sub-hypothesis, $\mathrm{H} 1 \mathrm{~b}$, investigated the significance of dividend policy on investment and financial decision-making. The wording of the questions and the relative 
Tab. 2: The relative frequency of answers to the question testing hypothesis $\mathrm{H1a}$

\begin{tabular}{|c|c|c|c|c|}
\hline 1. & 2. & 3. & 4. & 5. \\
\hline $\begin{array}{l}\text { Statement from the questionnaire } \\
\text { to which the respondents reacted }\end{array}$ & $\begin{array}{c}\text { Relative frequency } \\
\text { of answers supporting } \\
\text { the statement (\%) }\end{array}$ & $\begin{array}{c}\text { Relative frequency } \\
\text { of answers, „I don't } \\
\text { know“ (\%) }\end{array}$ & $\begin{array}{l}\text { Relative frequency of } \\
\text { answers in conflict with } \\
\text { the statement (\%) }\end{array}$ & Median \\
\hline \multirow{3}{*}{$\begin{array}{l}\text { H1 Dividend policy should attempt to } \\
\text { maximize firm value for shareholders }\end{array}$} & I strongly agree 47.62 & \multirow{3}{*}{16.67} & I strongly disagree 0.00 & \multirow{3}{*}{4} \\
\hline & I somewhat agree 35.71 & & I somewhat disagree 0.00 & \\
\hline & agreement $\mathbf{8 3 . 3 3}$ & & disagreement $\mathbf{0 . 0 0}$ & \\
\hline \multirow{3}{*}{$\begin{array}{l}\text { H2 Dividend policy is the main factor } \\
\text { which influences a firm's market value }\end{array}$} & I strongly agree 19.05 & \multirow{3}{*}{28.57} & I strongly disagree 0.0 & \multirow{3}{*}{4} \\
\hline & I somewhat agree 47.62 & & I somewhat disagree 4.76 & \\
\hline & agreement 66.67 & & disagreement 4.76 & \\
\hline \multirow{3}{*}{$\begin{array}{l}\text { H3 A change in the dividend } \\
\text { influences firm value }\end{array}$} & I strongly agree 11.90 & \multirow{3}{*}{28.57} & I strongly disagree 0.0 & \multirow{3}{*}{4} \\
\hline & I somewhat agree 42.86 & & I somewhat disagree 16.67 & \\
\hline & agreement 54.76 & & disagreement 16.67 & \\
\hline
\end{tabular}

\section{Tab. 3: The relative frequency of answers to the questions testing hypothesis $\mathrm{H} 1 \mathrm{~b}$}

\begin{tabular}{|c|c|c|c|c|}
\hline 1. & 2. & 3. & 4. & 5. \\
\hline $\begin{array}{l}\text { Statement from the questionnaire } \\
\text { to which the respondents reacted }\end{array}$ & $\begin{array}{l}\text { Relative frequency of } \\
\text { answers supporting the } \\
\text { statement (\%) }\end{array}$ & $\begin{array}{c}\text { Relative frequency } \\
\text { of answers, ,I don‘t } \\
\text { know“ (\%) }\end{array}$ & $\begin{array}{l}\text { Relative frequency of } \\
\text { answers in conflict with } \\
\text { the statement (\%) }\end{array}$ & Median \\
\hline \multirow{3}{*}{$\begin{array}{l}\text { F1 Dividends are paid after using all } \\
\text { other investment alternatives }\end{array}$} & I strongly agree 19.05 & \multirow{3}{*}{30.95} & I strongly disagree 0.00 & \multirow{3}{*}{4} \\
\hline & I somewhat agree 50.00 & & I somewhat disagree 0.00 & \\
\hline & agreement 69.05 & & disagreement $\mathbf{0 . 0 0}$ & \\
\hline \multirow{3}{*}{$\begin{array}{l}\text { F2 Investment, financial, and } \\
\text { dividend decisions are interrelated }\end{array}$} & I strongly agree 47.62 & \multirow{3}{*}{19.05} & I strongly disagree 0.00 & \multirow{3}{*}{4} \\
\hline & I somewhat agree 33.33 & & I somewhat disagree 0.00 & \\
\hline & agreement $\mathbf{8 0 . 9 5}$ & & disagreement 0.00 & \\
\hline \multirow{3}{*}{$\begin{array}{l}\text { F3 Financing investments with } \\
\text { undivided profits is cheaper than } \\
\text { external financing }\end{array}$} & I strongly agree 33.33 & \multirow{3}{*}{19.05} & I strongly disagree 0.00 & \multirow{3}{*}{4} \\
\hline & I somewhat agree 47.61 & & I somewhat disagree 0.00 & \\
\hline & agreement 80.94 & & disagreement $\mathbf{0 . 0 0}$ & \\
\hline \multirow{3}{*}{$\begin{array}{l}\text { F4 Dividends represent a flexible tool } \\
\text { for optimizing capital structure }\end{array}$} & I strongly agree 23.81 & \multirow{3}{*}{47.62} & I strongly disagree 0.0 & \multirow{3}{*}{3} \\
\hline & I somewhat agree 19.05 & & I somewhat disagree 9.52 & \\
\hline & agreement 42.85 & & disagreement 9.52 & \\
\hline \multirow{3}{*}{$\begin{array}{l}\text { F5 Financing with the help of } \\
\text { retained earnings rather than } \\
\text { externally is subject to less control by } \\
\text { external creditors }\end{array}$} & I strongly agree 28.57 & \multirow{3}{*}{47.61} & I strongly disagree 0.00 & \multirow{3}{*}{3} \\
\hline & I somewhat agree 4.76 & & I somewhat disagree 19.05 & \\
\hline & agreement 33.32 & & disagreement 19.05 & \\
\hline \multirow{3}{*}{$\begin{array}{l}\text { F6 Dividend policy influences capital } \\
\text { costs }\end{array}$} & I strongly agree 14.28 & \multirow{3}{*}{47.62} & I strongly disagree 0.00 & \multirow{3}{*}{3.5} \\
\hline & I somewhat agree 38.09 & & I somewhat disagree 0.00 & \\
\hline & agreement $\mathbf{5 2 . 3 7}$ & & disagreement 0.00 & \\
\hline
\end{tabular}


frequency of answers expressing the position of respondents to investment and financial decision-making are shown in Table 3.

Appropriately established corporate investment and financial strategy can increase firm value. Within investment decision-making, this means the choice of effective investment alternatives; from the perspective of financial decision-making, this means optimizing the company's capital structure. The benefit of this strategy lies in raising company profit, which can be subsequently distributed to shareholders in the form of dividends. This set dividend policy is the result of investment and financial decisions. Of the respondents, $80.95 \%$ agreed with the statement that investment, financial and dividend decisions are interrelated; this statement is statistically significant.

On the other hand, the relationship between dividend policy, investments and capital structure can be the reverse. This situation arises in the case of residual dividend policy, where dividends are paid only when all investments have been carried out and the company still has residual funds available. The statement that dividends are paid after implementing all other investments had a strong or slight agreement rate of $69.05 \%$ among managers and is statistically significant.

In relation to investment decision-making, there is residual policy, which renders "more flexible" dividends more attractive. According to the pecking order theory, this is because management prioritized undivided profit over issuing shares or bonds during financing because of high flotation costs. Undivided profit can be the only source of financing in the case of restriction of access to sources on the financial market. The statement that financing investments with undivided profit is cheaper than external financing is statistically significant and gained a strong or slight agreement rate of $80.9 \%$ from respondents.

Moreover, management yields greater control to the side of investors when using external financing. The statement that financing with the help of retained earnings rather than externally is subject to less control by external creditors had a strong or slight agreement rate of $33.3 \%$ of respondents. This conclusion can relate to the fact that, in the case of a dominant shareholder, this shareholder watches over the management to make sure there will be no ineffective spending of financial resources. It is necessary to add that, for this statement, a large amount of respondents did not have an opinion, which is statistically significant.

Dividend payout means a change in the structure of financial sources. Unpaid dividends strengthen owned capital at the expense of borrowed capital and the reverse. With the correct choice of composition of owned and borrowed capital, management sets the balance between risk and yield with the goal of maximizing the enterprise's value. The statement that dividends represent a flexible tool for optimizing capital structure had a rate of $42.85 \%$ of respondents having slight or strong agreement.

Raising the rate of external sources in relation to internal sources raises the firm's risk level from the creditors' perspective; thereby, the willingness of creditors to lend to the company will decrease and borrowing costs will be higher. On the other hand, not paying dividends and thereby strengthening owned capital creates better conditions for capital acquisition costs. The statement that dividend policy influences capital costs had strong or slight agreement from $52.37 \%$ of respondents. On the basis of the number of answers supporting the individual statement, it is possible to confirm the given hypothesis $\mathrm{H} 1 \mathrm{~b}$.

The third sub-hypothesis, H1c, concerns the theory of signaling. According to this theory, dividends are a signaling mechanism by which companies can lower information asymmetry between management and shareholders. By means of changes in dividend policy, investors can deduce information about future company performance. The respondents' opinions on the significance of dividends as a means of information transfer between managers and shareholders is shown in Table 4 below. 


\section{Tab. 4: The relative frequency of answers to the questions testing hypothesis H1c}

\begin{tabular}{|c|c|c|c|c|}
\hline 1. & 2. & 3. & 4. & 5. \\
\hline $\begin{array}{l}\text { Statement from the questionnaire } \\
\text { to which the respondents reacted }\end{array}$ & $\begin{array}{l}\text { Relative frequency of } \\
\text { answers supporting the } \\
\text { statement (\%) }\end{array}$ & $\begin{array}{c}\text { Relative frequency } \\
\text { of answers, ,I don't } \\
\text { know“ (\%) }\end{array}$ & $\begin{array}{l}\text { Relative frequency of } \\
\text { answers in conflict with } \\
\text { the statement (\%) }\end{array}$ & Median \\
\hline \multirow{3}{*}{$\begin{array}{l}\text { S1 The dividend represents one } \\
\text { of the main tools investors use to } \\
\text { evaluate corporate performance }\end{array}$} & I strongly agree 23.80 & \multirow{3}{*}{26.19} & I strongly disagree 0.00 & \multirow{3}{*}{4} \\
\hline & I somewhat agree 40.48 & & I somewhat disagree 9.52 & \\
\hline & agreement 64.28 & & disagreement 9.52 & \\
\hline \multirow{3}{*}{$\begin{array}{l}\text { S2 Dividends represent unused } \\
\text { financial resources for profitable } \\
\text { projects }\end{array}$} & I strongly agree 16.67 & \multirow{3}{*}{30.95} & I strongly disagree 19.04 & \multirow{3}{*}{3} \\
\hline & I somewhat agree 21.52 & & I somewhat disagree 11.90 & \\
\hline & agreement 38.19 & & disagreement 30.94 & \\
\hline \multirow{3}{*}{$\begin{array}{l}\text { S3 A decrease (increase) in the } \\
\text { dividend signals deterioration } \\
\text { (improvement) of future profits }\end{array}$} & I strongly agree 0.00 & \multirow{3}{*}{45.23} & I strongly disagree 0.00 & \multirow{3}{*}{3} \\
\hline & I somewhat agree 28.57 & & I somewhat disagree 26.21 & \\
\hline & agreement $\mathbf{2 8 . 5 7}$ & & disagreement 26.21 & \\
\hline \multirow{3}{*}{$\begin{array}{l}\text { S4 The company should } \\
\text { communicate reasons for changes in } \\
\text { dividend amount with investors }\end{array}$} & I strongly agree 35.71 & \multirow{3}{*}{21.43} & I strongly disagree 0.00 & \multirow{3}{*}{4} \\
\hline & I somewhat agree 28.57 & & I somewhat disagree 14.29 & \\
\hline & agreement 64.28 & & disagreement 14.29 & \\
\hline \multirow{3}{*}{$\begin{array}{l}\text { S5 If there are other tools for } \\
\text { imparting market information, then } \\
\text { the dividend does not represent an } \\
\text { important signal }\end{array}$} & I strongly agree 0.00 & \multirow{3}{*}{52.38} & I strongly disagree 0.00 & \multirow{3}{*}{3} \\
\hline & I somewhat agree 40.48 & & I somewhat disagree 7.14 & \\
\hline & agreement $\mathbf{4 0 . 4 8}$ & & disagreement 7.14 & \\
\hline \multirow{3}{*}{$\begin{array}{l}\text { S6 When determining corporate } \\
\text { strategy, other firms' dividend policy } \\
\text { trends are taken into consideration }\end{array}$} & I strongly agree 0.00 & \multirow{3}{*}{69.04} & I strongly disagree 4.77 & \multirow{3}{*}{3} \\
\hline & I somewhat agree 9.52 & & I somewhat disagree 16.67 & \\
\hline & agreement 9.52 & & disagreement 21.44 & \\
\hline
\end{tabular}

From the data in the table, it can be said that of the statements expressing support for the dividend mechanism's importance, the most supported statements were that the dividend represents one of the main tools investors use to evaluate corporate performance, which gained $64.28 \%$ agreement, and the statement that the company should communicate reasons for changes in dividend amount with investors, which was supported by $64.28 \%$ of respondents. The importance of dividends is also supported by the statement that if there are other tools for imparting market information, then the dividend does not represent an important signal, which was not endorsed by only $7.14 \%$ of the respondents.

The thesis that dividend change indicates a change in future profits was not proved for the companies studied. The statement that a decrease (increase) in the dividend signals deterioration (improvement) of future profits showed agreement of $28.57 \%$ and no opinion on the given problematic for $45.23 \%$ of respondents; this statement is without statistical repercussions. This conclusion corresponds to the support for statement S5 that when reasons for dividend change are shared, then the dividend need not indicate change in company performance. Managers can react to an investment opportunity by lowering or not paying the dividend and the reverse. Related to this is the statement that dividends represent unused financial resources for profitable projects, which gained a mere $38.19 \%$ of agreement from the respondents and is without statistical repercussion.

The statement that when determining corporate strategy, other firms' dividend policy trends are taken into consideration has a disagreement rate of $21.44 \%$ of respondents; this disagreement is statistically significant. This viewpoint also corresponds with factor F15 Dividend policy in accordance with the 
competition listed in question four - respondents consider this of low importance when deciding dividend payout.

On the basis of the number of answers expressing the respondents' position on individual questions, it is not possible to confirm the given hypothesis $\mathrm{H} 1 \mathrm{c}$.

The fourth sub-hypothesis, $\mathrm{H} 1 \mathrm{~d}$, investigated the respondents' opinions as to whether dividends can serve as a tool for limiting agency problems between shareholders (investors) and managers. The problem occurs when managers act in their own interests and do not take the shareholders' interests into sufficient consideration. The wording of the questions and relative frequency of answers expressing the respondents' positions on the importance of dividends as a tool for reducing the agency problem between shareholders and management are listed in Table 5 below.

\begin{tabular}{|c|c|c|c|c|}
\hline 1. & 2. & 3. & 4. & 5. \\
\hline $\begin{array}{l}\text { Statement from the questionnaire } \\
\text { to which the respondents reacted }\end{array}$ & $\begin{array}{l}\text { Relative frequency of } \\
\text { answers supporting the } \\
\text { statement (\%) }\end{array}$ & $\begin{array}{l}\text { Relative frequency } \\
\text { of answers, ,I don't } \\
\text { know" (\%) }\end{array}$ & $\begin{array}{l}\text { Relative frequency of } \\
\text { answers in conflict with } \\
\text { the statement (\%) }\end{array}$ & Median \\
\hline \multirow{3}{*}{$\begin{array}{l}\text { N1 The dividend serves as a tool } \\
\text { to make managers act in the } \\
\text { shareholders' interest }\end{array}$} & I strongly agree 2.38 & \multirow{3}{*}{45.24} & I strongly disagree 2.38 & \multirow{3}{*}{3} \\
\hline & I somewhat agree 40.24 & & I somewhat disagree 9.52 & \\
\hline & agreement 42.62 & & disagreement 11.9 & \\
\hline \multirow{3}{*}{$\begin{array}{l}\text { N2 Raising the dividend lowers the } \\
\text { shareholders' need to supervise } \\
\text { management }\end{array}$} & I strongly agree 0.00 & \multirow{3}{*}{21.43} & I strongly disagree 19.05 & \multirow{3}{*}{2} \\
\hline & I somewhat agree 14.28 & & I somewhat disagree 45.24 & \\
\hline & agreement 14.28 & & disagreement 64.29 & \\
\hline \multirow{3}{*}{$\begin{array}{l}\text { N3 The dividend forces businesses } \\
\text { to look for external sources of } \\
\text { financing, which raises the level of } \\
\text { control shareholders and creditors } \\
\text { have over management }\end{array}$} & I strongly agree 0.00 & \multirow{3}{*}{54.76} & I strongly disagree 7.14 & \multirow{3}{*}{3} \\
\hline & I somewhat agree 7.14 & & I somewhat disagree 30.95 & \\
\hline & agreement 7.14 & & disagreement 38.09 & \\
\hline
\end{tabular}

The predominantly high level of disagreement with individual statements does not support the importance of dividends for resolving agency problems between shareholders and management. Respondents registered the most explicit disagreement to the statement that raising the dividend lowers the shareholders' need to supervise management; $64.29 \%$ of respondents disagreed with this to a greater or lesser degree. The statement that the dividend forces businesses to look for external sources of financing, which raises the level of control shareholders and creditors have over management showed disagreement of $38 \%$ of respondents and is statistically significant. The respondents listed only agreement with the first statement that the dividend serves as a tool to make managers act in the shareholders' interest. This agreement could be caused by a combination of misunderstanding the questions and the fact that respondents consider F5 Existing shareholder requirements to be the most important factor in dividend policy. In addition to the higher level of disagreement, respondents often responded to individual statements with "I don't know, without opinion." These respondents' positions indicate either unfamiliarity with the given problem or that other tools are used in resolving conflict between management and shareholders.

On the basis of the number of answers expressing respondents' positions on individual questions, it is not possible to confirm the given hypothesis, $\mathrm{H} 1 \mathrm{~d}$.

The fifth sub-hypothesis, H1e, investigated the respondents' opinions on how ownership structure can influence corporate dividend policy and thereby indirectly influence firm value as well. In the case that ownership is in the hands of one individual, such individuals usually manage the firm by themselves or select and supervise management and provide 
individual decisions autonomously with the goal of maximizing their own wealth. However, companies are characterized by various forms of part-ownership, in which there are multiple owners. Individual shareholders can have various reasons for distributing dividends or a goal concerning dividend amount or retaining profit for reinvestment. The wording of the questions and the relative frequency of answers expressing the respondents' positions on shareholder importance in dividend policy are listed in Table 6 below.

\section{Tab. 6: The relative frequency of answers to the questions testing hypothesis H1e}

\begin{tabular}{|c|c|c|c|c|}
\hline 1. & 2. & 3. & 4. & 5. \\
\hline $\begin{array}{l}\text { Statement from the questionnaire } \\
\text { to which the respondents reacted }\end{array}$ & $\begin{array}{l}\text { Relative frequency of } \\
\text { answers supporting the } \\
\text { statement (\%) }\end{array}$ & $\begin{array}{c}\text { Relative } \\
\text { frequency } \\
\text { of answers, } \\
\text { „I don't know“ } \\
(\%)\end{array}$ & $\begin{array}{l}\text { Relative frequency of } \\
\text { answers in conflict with } \\
\text { the statement (\%) }\end{array}$ & Median \\
\hline \multirow{3}{*}{$\begin{array}{l}\text { A1 Shareholder requirements are an } \\
\text { important factor in decision-making } \\
\text { concerning dividend policy }\end{array}$} & I strongly agree 66.67 & \multirow{3}{*}{4.76} & I strongly disagree 0.00 & \multirow{3}{*}{5} \\
\hline & I somewhat agree 28.57 & & I somewhat disagree 0.00 & \\
\hline & agreement 95.24 & & disagreement $\mathbf{0 . 0 0}$ & \\
\hline \multirow{3}{*}{$\begin{array}{l}\text { A2 Shareholders prefer a cash } \\
\text { dividend rather than a higher, } \\
\text { unpredictable capital profit }\end{array}$} & I strongly agree 38.07 & \multirow{3}{*}{28.57} & I strongly disagree 0.00 & \multirow{3}{*}{4} \\
\hline & I somewhat agree 21.43 & & I somewhat disagree 11.91 & \\
\hline & agreement 59.52 & & disagreement 11.91 & \\
\hline \multirow{3}{*}{$\begin{array}{l}\text { A3 The company creates dividend } \\
\text { policy on the basis of the main } \\
\text { shareholders' requirements }\end{array}$} & I strongly agree 85.71 & \multirow{3}{*}{4.76} & I strongly disagree 0.00 & \multirow{3}{*}{5} \\
\hline & I somewhat agree 9.52 & & I somewhat disagree 0.00 & \\
\hline & agreement 95.23 & & disagreement 0.00 & \\
\hline \multirow{3}{*}{$\begin{array}{l}\text { A4 Shareholders prefer stable } \\
\text { dividends }\end{array}$} & I strongly agree 21.43 & \multirow{3}{*}{19.04} & I strongly disagree 7.14 & \multirow{3}{*}{4} \\
\hline & I somewhat agree 30.95 & & I somewhat disagree 21.43 & \\
\hline & agreement $\mathbf{5 2 . 3 8}$ & & disagreement 28.57 & \\
\hline \multirow{3}{*}{$\begin{array}{l}\text { A5 Tax incidence for shareholders is } \\
\text { an important factor when decision- } \\
\text { making concerning dividend policy }\end{array}$} & I strongly agree 19.05 & \multirow{3}{*}{16.67} & I strongly disagree 0.00 & \multirow{3}{*}{4} \\
\hline & I somewhat agree 52.38 & & I somewhat disagree 11.90 & \\
\hline & agreement 71.43 & & disagreement 11.90 & \\
\hline \multirow{3}{*}{$\begin{array}{l}\text { A6 Majority and minority } \\
\text { shareholders have differing dividend } \\
\text { preferences }\end{array}$} & I strongly agree 30.95 & \multirow{3}{*}{35.71} & I strongly disagree 7.14 & \multirow{3}{*}{3} \\
\hline & I somewhat agree 14.29 & & I somewhat disagree 11.90 & \\
\hline & agreement $\mathbf{4 5 . 2 4}$ & & disagreement 19.04 & \\
\hline \multirow{3}{*}{$\begin{array}{l}\text { A7 Internal and external } \\
\text { shareholders have differing dividend } \\
\text { preferences }\end{array}$} & I strongly agree 11.90 & \multirow{3}{*}{40.47} & I strongly disagree 7.14 & \multirow{3}{*}{3} \\
\hline & I somewhat agree 23.81 & & I somewhat disagree 16.67 & \\
\hline & agreement 35.71 & & disagreement $\mathbf{2 3 . 8 1}$ & \\
\hline
\end{tabular}

Respondents gave the most explicit agreement to the statements that shareholder requirements are an important factor in decisionmaking concerning dividend policy and the company creates dividend policy on the basis of the main shareholders' requirements; 95\% of respondents agreed with these statements, which is statistically significant. These overall positions of agreement are consistent with the conclusions of the research question in which respondents listed the most important factor when making decisions as F5 Existing shareholder requirements.

In the Czech Republic, the system of taxing dividends is founded on the classic system, which consists of the separation of taxed 
profits and dividends - without their being mutually interrelated in any way. Dividend taxation is performed by withholding tax at a rate of $15 \%$. The statement that tax incidence for shareholders is an important factor when decision-making concerning dividend policy indicated agreement by $71.4 \%$ of respondents and is statistically significant. In relation to the affirmative statement $\mathrm{A} 2$ and low state of debt of the observed businesses, freeing dividends from tax could result in raising the number of companies with dividend payout.

The statement that shareholders prefer a cash dividend rather than a higher, unpredictable capital profit received agreement from $59.5 \%$ of respondents. A similarly significant level of agreement was shown by the statement that shareholders prefer stable dividends. It is possible to interpret this position as the fact that shareholders do not trust managers to invest undivided profit reasonably or that they have doubts about management abusing financial resources.

The statements $A 6$ and $A 7$ commented on the differences in dividend preferences between majority and minority shareholders and between internal and external shareholders. In both cases, the affirmative position was predominant among respondents, but, in the case of the statement that internal and external shareholders have differing dividend preferences, this agreement was statistically insignificant.

From the number of answers supporting the statements, it is possible to confirm hypothesis $\mathrm{H} 1 \mathrm{e}$. This is in accordance with the conclusions of the research question concerning which factors influence management when making decisions about dividend payout, for which the most important factor was listed as F5 Existing shareholder requirements.

\section{Conclusion}

One of the key areas of corporate financial management is decision-making concerning the distribution of economic results. The dividend can be considered to be one option for distributing economic results while fulfilling legal conditions. For many shareholders, dividend payout is an important part of their decisionmaking concerning investments.

The goal of this article was to identify factors that influence management in the investigated sector when making decisions about dividend payout. The respondents had twenty factors to choose from. The survey made it clear that the most important factors for management are the following: (1) the requirements of existing shareholders, (2) access to funds, (3) the actual amount of profit and (4) maintaining the target state of debt. All these factors were of aboveaverage importance and statistically significant on the basis of the t-test. There were another six indicators with average importance, however, none of them showed statistical significance at a significance of $\alpha=0.05$. Managers considered the remaining factors to be of below-average importance.

Especially in academic circles, the most commonly accepted theory is the theory of dividend neutrality, which says that firm value is entirely independent of its dividend policy. According to critics of this theory, the prerequisites considered are too abstract and unusable in the real financial world. Therefore, another goal of this article was to determine the respondents' position on whether and how dividend policy influences firm value. With this in mind, the hypothesis that dividend payout influences market imperfections, which result in influencing firm value was formulated. The answer to this hypothesis was achieved by formulating five sub-hypotheses.

Research results supported the validity of the base hypothesis. However, hypotheses $\mathrm{H} 1 \mathrm{c}$ and $\mathrm{H} 1 \mathrm{~d}$ do not provide support for dividends in favor of lowering information asymmetry and agency costs between management and shareholders. This conclusion can be caused by the respondents' insufficient theoretical knowledge of the given problematic. Another cause can be ownership structure, when the firms investigated are characterized by high ownership concentration, i.e., when the companies are governed by one or two significant shareholders. An important shareholder is able to protect other shareholders from management implementing their own interests. In these cases, it is possible to expect that there will be no information asymmetry between the shareholders and the management, resulting in no agency conflict or its consequent costs. Knowledge of the most important factors for dividend payout enables existing shareholders and potential investors to make decisions more objectively. Businessmen with stocks and financial advisers can also use the research results practically for appropriately 
timing clients' investments to receive dividend yields.

From the research conducted, it is clear that shareholder requirements are the most important factor when shaping dividend policy for the investigated companies. To this end, this primary research was expanded into secondary research. Seven regressive models were composed to identify and define the strength of individual factors for dividend payout among individual types of shareholders. Likewise, the results of this research will be published subsequently.

\section{References}

[1] ASQUITH, P., MULLINS, Jr, D.W. The impact of initiating dividend payments on shareholders wealth. Journal of Business. 1983, Vol. 56, Iss. 1, pp.77-96. ISSN 0148-2963.

[2] BENARTZI, S., MICHAELY, R., THALER, $R$. Do changes in dividends signal the future or the past? Journal of Finance. 1997, Vol. 52, Iss. 3, pp. 1007-1043. ISSN 1540-6261. DOI:10.1111/j.1540-6261.1997.tb02723.x

[3] BENARTZI, S., MICHAELY, R., THALER, R.H. Dividend Changes Do Not Signal Changes in Future Profitability. Journal of Business. 2005, Vol. 78, Iss. 5, pp.1659-1682. ISSN 0148-2963.

[4] BHATTACHARYA, S. Imperfect information, dividend policy, and "the bird in the hand" fallacy. The Bell Journal of Economics. 1979, Vol. 10, Iss. 1, pp. 259-270. ISSN 0005-8556.

[5] BROCKMAN, P., UNLU, E. Dividend policy, creditor rights, and the agency costs of debt. Journal of Financial Economics. 2009, Vol. 92, Iss. 2, pp. 276-299. ISSN 0304-405X.

[6] BROCKMAN, P., UNLU, E. Earned/ contributed capital, dividend policy, and disclosure quality: An international study. Journal of Banking \& Finance. 2011, Vol. 35, Iss. 7, pp.1610-1625. ISSN 0378-4266. DOI:10.1016/j.jbankfin.2010.11.014.

[7] BYRNE, J., O'CONNOR, T. Creditor rights and the outcome model of dividends. The Quarterly Review of Economics and Finance. 2012, Vol. 52, Iss. 2, pp. 227-242. ISSN 10629769. DOI:10.1016/j.qref.2012.04.002.

[8] DEANGELO, H., DEANGELO, L., STULZ, R.M. Dividend policy and the earned/ contributed capital mix: a test of the life-cycle theory. Journal of Financial Economics. 2006, Vol. 8, Iss. 2, pp. 227-254. ISSN 0304-405X. DOI:10.1016/j.jfineco.2005.07.005.

[9] DUSPIVA, P., NOVOTNÝ, J. Utilization of Quantitative Methods in the Decision Making
Process of a Manager. Scientific Papers of the University of Pardubice. Series D, Faculty of Economics and Administration. 2010, Vol. 17, Iss. 2, pp. 63-69. ISSN 1211-555X.

[10] EASTERBROOK, F.H. Two agencycost explanations of dividends. The American Economic Review. 1984, Vol. 74, Iss. 4, pp. 650659. ISSN 0002-8282.

[11] ELTON, E.J., GRUBER, M.J. Marginal stockholder tax rates and the clientele effect. The Review of Economics and Statistics. 1970, Vol. 52, Iss. 1, pp. 68-74. ISSN 0034-6535.

[12] FAMA, E.F., FRENCH, K.R. Disappearing dividends: changing firm characteristics or lower propensity to pay? Journal of Financial Economics. 2001, Vol. 60, Iss. 1, pp. 3-43. ISSN 0304-405X. DOI:10.1016/S0304-405X(01)00038-1.

[13] GAZDA, J., ČÁBELKA, J. Dividendová politika $v$ České republice. Praha: HZ Editio spol. s.r.o., 2002. ISBN 80-86009-39-4.

[14] HEALY, P.M., PALEPU, K.G. Earnings Information Conveyed by Dividend Initiations and Omissions. Journal of Financial Economics. 1988, Vol. 21, Iss. 2, pp. 149-176. ISSN 0304405X. DOI:10.1016/0304-405X(88)90059-1.

[15] HRUŠKA, R., PRŮŠA, P., BABIČ, D. The use of AHP method for selection of supplier. Transport. 2014, Vol. 29, Iss. 2, pp. 195-203. ISSN 1648-4142. DOI:10.3846/16484142.201 4.930928.

[16] CHAE, J., KIM, S., LEE, E.J. How corporate governance affects payout policy under agency problems and external financing constraints. Journal of Banking \& Finance. 2009, Vol. 33, Iss. 11, pp. 2093-2101. ISSN 0378-4266. DOI:10.1016/j.jbankfin.2009.05.003.

[17] JENSEN, M.C. Agency costs of free cash flow, corporate finance, and takeovers. The Americian Economic Review. 1986, Vol. 76, Iss. 2, pp. 323-329. ISSN 0002-8282.

[18] JENSEN, M.C., MECKLING, W.H. Theory of the firm: Managerial behavior, agency costs and ownership structure. Journal of Financial Economics. 1976, Vol. 3, Iss. 4, pp. 305360. ISSN 0304-405X. DOI:10.1016/0304405X(76)90026-X.

[19] JO, H., PAN, C. Why are firms with entrenched managers more likely to pay dividends? Review of Accounting and Finance. 2009, Vol. 8, Iss. 1, pp. 87-116. ISSN 1475-7702. [20] JOHN, K., WILLIAMS, J. Dividends, Dilution, and Taxes: A Signaling Equilibrium. Journal of Finance. 1985, Vol. 40, Iss. 4, pp. 1053-1070. ISSN 1351-847X. 
[21] KORKEAMAKI, T., LILJEBLOM, E., PASTERNACK, D. Tax reform and payout policy: Do shareholder clienteles or payout policy adjust? Journal of Corporate Finance. 2010, Vol. 16, Iss. 4, pp. 572-587. DOI:10.1016/j. jcorpfin.2009.12.003.

[22] LA PORTA, R., LOPEZ-DE SILANES, F., SHLEIFER, A., VISHNY, R.W. Agency problem and dividend policies around the World. The Journal of Finance. 2000, Vol. 55, Iss. 1, pp. 1-33. ISSN 0022-1082. DOI: 10.1111/00221082.00199.

[23] LEARY, M.T., MICHAELY, R. Determinants of dividend smoothing: empirical evidence. The Review of Financial Studies. 2011, Vol. 24 , Iss. 10 , pp. 3197-3249. ISSN 0893-9454. DOI:10.1093/rfs/hhr072.

[24] LEASE, R.C., et al. Dividend Policy: Its Impact on Firm Value. Oxford: Oxford University Press, 1999. ISBN 0-87584-497-9.

[25] LINTNER, J. Distribution of Incomes of corporations among dividends, retained earnings, and taxes. American Economic Rewiew. 1956, pp. 97-113. ISSN 0002-8282.

[26] MICHAELY, R., ROBERTS, M. Dividend smoothing, agency costs, and information asymmetry: Lessons from the dividend policies of private firms. Cornell University and IDC, 2006. 63 p. Working paper.

[27] MILLER, M.H., MODIGLIANI, F. Dividend policy, growth, and the valuation of shares. Journal of Business. 1961, Vol. 34, Iss. 4, pp. 411-433. ISSN 2233-369X.

[28] MILLER, M.H., ROCK, K. Dividend policy under asymmetric information. The Journal of Finance. 1985, Vol. 40, Iss. 4, pp. 1031-1051. ISSN 1540-6261. DOI:10.1111/j.1540-6261.1985.tb02362.x.

[29] MYŠKOVÁ, R. Company Information Systems Used in Decisions-Making Processes of Financial Managers. WSEAS Transaction on Systems. 2009, Vol. 8, Iss. 4, pp. 532-542. ISSN 1109-2777.
[30] MYŠKOVÁ, R. Satisfaction of Financial Managers with Accounting Information System. In: Proceedings of the $3^{\text {rd International }}$ Conference on Management, Marketing and Finances. Advances in Marketing, Management and Finances. Houston: WSEAS Press, 2009. pp. 76-81. ISSN 1790-2769.

[31] NASH, R.C., NETTER, J.M., POULSEN, A.B. Determinants of contractual relation between shareholders and bondholders: investment opportunities and restrictive covenants. Journal of Corporate Finance. 2003, Vol. 9, Iss. 2, pp. 201-232. ISSN 0929-1199. DOI:10.1016/S0929-1199(02)00007-X.

[32] NISSIM, D., ZIV, A. Dividend changes and future profitability. The Journal of Finance. 2001, Vol. 61, Iss. 6, pp. 2111-2133. ISSN 1540-6261.

[33] ROUBÍČKOVÁ, M. Závažnost dividendové politiky a její aplikace firmami v České republice. In: 5. mezinárodní konference Finanční rízení podniku a finančních institucí, 2005. Ostrava: VŠB-TU. ISBN 80-248-0938-9.

[34] SHLEIFER, A., VISHNY, R.W. A survey of corporate governance. The Journal of Finance. 1997, Vol. 52, Iss. 2, pp. 737-783. ISSN 15406261. DOI:10.1111/j.1540-6261.1997.tb04820.x. [35] TRAVLOS, N.G., MILONAS, N.T. The ex-dividend Day Stock Price Behavior in the Athens Stock Exchange, 2001. In: EFMA 2001 Lugano Meetings.

Ing. František Sejkora, Ph.D. University of Pardubice

Faculty of Economics and Administration Institute of Business Economics and Management frantisek.sejkora@upce.cz

doc. Ing. Pavel Duspiva, CSc. University of Pardubice

Faculty of Economics and Administration Institute of Business Economics and Management pavel.duspiva@upce.cz 


\section{Abstract}

\section{THE POSITION OF MANAGEMENT OF CZECH JOINT-STOCK COMPANIES ON DIVIDEND POLICY}

\section{František Sejkora, Pavel Duspiva}

The concept of distributing economic results belongs unequivocally among management's basic financial decisions. Dividend payout to shareholders can be considered to be the distribution of economic results while fulfilling legal conditions. The goal of this article is to identify factors that have a fundamental influence on dividend payout and to further determine and evaluate the position of management on dividend theories. This problematic is current for the conditions of Czech joint-stock companies, because deeper studies in this area are not available for recent years. Nevertheless, currently, the greater majority of joint-stock companies now regularly pay dividends, and dividend policy has become a part of their financial policy that is impossible to overlook. With regards to the fact that profit is the necessary condition for dividend payout, research was aimed at the sector, "Production and Distribution of Electricity, Gas and Water," which is most interesting among Czech joint-stock companies from the perspective of profitability and frequency of dividend payout. For the reasons of quantitative research, a two-part questionnaire was created for workers in financial management - specifically, members of the executive board, who are assumed to have comprehensive knowledge and an overview of the company. The survey showed that the most important factors for management when making decisions concerning dividend payout are the following: the requirements of existing shareholders, access to funds, the actual amount of profit and maintaining the target state of debt. Further results confirmed that dividend policy does influence firm value. However, dividends are not supported as a tool for lowering information asymmetry and agency costs between management and shareholders. This conclusion can be caused by ownership structure when the firms investigated are characterized by high concentration of ownership; then, one shareholder is able to better protect the other shareholders against the implementation of management's interests.

Key Words: Dividend policy, factors, value of the company, management, shareholders.

JEL Classification: G35.

DOI: 10.15240/tul/001/2015-2-006 